\title{
EVALUATION OF ACTIVITIES AND NEEDS OF OLDER WORKERS IN THE CONTEXT OF MAINTAINING THEIR EMPLOYMENT
}

\author{
OCENA DZIAŁAŃ I POTRZEBY STARSZYCH PRACOWNIKÓW W KONTEKŚCIE UTRZYMYWANIA ICH W ZATRUDNIENIU
}

Central Institute for Labour Protection - National Research Institute / Centralny Instytut Ochrony Pracy -

Państwowy Instytut Badawczy, Warszawa, Poland

Department of Ergonomics, Laboratory of Physiology and Hygiene of Work / Zakład Ergonomii, Pracownia Fizjologii i Higieny Pracy

\begin{abstract}
Background: The article presents the results of evaluation of activities for older workers (50+). The aim of the study was the examination of older workers' opinions on activities undertaken in their companies related to maintaining older workers' employment. Material and Methods: Data is derived from the questionnaire survey conducted on 50+ employees (250 women and 250 men). Results: Almost one fifth of the employees admitted that they feel discriminated against in their company. Only a quarter of older workers declared that they had special offer of trainings, most of them concerned update trainings, expending knowledge ( $40 \%$ of responses). Only about one fifth of respondents admitted that they were encouraged to further their education. The smallest number of actions concerned health promotion. Conclusions: Older workers have different needs than younger ones, especially in the organization and working conditions. Activities related to the management of aging in Poland are still taken to a small extent. Disturbing is the fact that so few respondents admitted that in their companies, there were activities conducted concerning health promotion. From the point of view of working capacity and extending the retirement age, such initiatives should be carried out on a large scale among workers of all ages, with particular emphasis on the elderly. Med Pr 2013;64(3):297-306
\end{abstract}

Key words: older employees, needs, age management

\begin{abstract}
STRESZCZENIE
Wstęp: W artykule zaprezentowano wyniki badań dotyczących działań związanych z zarządzaniem wiekiem w Polsce w opiniach starszych pracowników (50+). Cel pracy: Celem było zbadanie opinii starszych pracowników na temat działań podejmowanych w ich przedsiębiorstwach w zakresie utrzymywania w zatrudnieniu osób 50+. Materiał i metody: Dane pochodzą z wywiadu kwestionariuszowego przeprowadzonego wśród 500 pracowników w wieku 50+ (250 kobiet i 250 mężczyzn). Wyniki: Prawie 1/5 pracowników przyznała, że czuje się dyskryminowana w swojej firmie. Zaledwie 1/4 starszych pracowników zadeklarowała istnienie szkoleń adresowanych do nich; przy czym najwięcej z nich dotyczyło aktualizacji/poszerzania wiedzy (40\% wskazań). Tylko około $1 / 5$ badanych przyznała, że była zachęcana do dalszego kształcenia. Najmniej działań adresowanych do starszych pracowników dotyczyło zagadnień związanych z dbałością o zdrowie. Wnioski: Działania związane z zarządzaniem wiekiem w Polsce są podejmowane nadal w niewielkim stopniu. Starsi pracownicy mają inne niż młodsi potrzeby w zakresie organizacji i warunków pracy. Niepokojące jest, że tak niewiele spośród badanych osób informowało o działaniach związanych z dbałością o zdrowie prowadzonych w ich przedsiębiorstwach. Z punktu widzenia zdolności do pracy oraz wydłużania wieku emerytalnego takie inicjatywy powinny być prowadzone na szeroką skalę wśród pracowników w każdym wieku, ze szczególnym uwzględnieniem osób starszych. Med. Pr. 2013;64(3):297-306
\end{abstract}

Słowa kluczowe: pracownicy starsi, potrzeby, zarządzanie wiekiem

Author's address: Department of Ergonomics, Laboratory of Physiology and Hygiene of Work,

Central Institute for Labour Protection - National Research Institute,

ul. Czerniakowska 16, 00-701 Warszawa, e-mail: kahil@ciop.pl

Received: 2013, April 15, accepted: 2013, July 22

\section{INTRODUCTION}

In most European countries, especially in Poland, an increase in the population of persons above 50 years of age has been observed. This is due to the generation of people born after World War II (the so-called "baby boomers") gradually reaching this age and the observed decline of fertility rate over the last decades. In terms of the labour market, it means the decrease in the number of persons at their productivity age.

According to Eurostat data (2012), employment rate among persons aged between 55-64 in Poland in 2011 was $36.9 \%$ ( $27.3 \%$ for women, $47.8 \%$ for men). Although the rate increased, as compared to the previous year (2010 - 34\%, including $24.2 \%$ of women, and $45.3 \%$ of men), it is still one of the lowest rates in 
the EU. The average rate for the $\mathrm{EU}$ is $47.7 \%$ ( $40.2 \%$ for women, $55.2 \%$ for men) (1).

Currently, various activities are being undertaken in order to minimize the consequences of the unavoidable process of aging. One of them is called "age management", it is defined as an element of human resources management or a part of widely-understood diversity management (combating age, gender and religious discrimination). Its objective is to conduct activities which allow for a more effective use of human resources in companies by taking into account the needs and capabilities of employees of all ages (2). The scope of activities targeted at employees above 50 years old, which are performed for the purpose of effective age management, includes initiatives related to: recruitment, health care, lifelong learning, career development, and organization of work and working conditions.

The purpose of this study was to analyze the opinion of older employees on the activities implemented at their companies in terms of maintaining the employment of $50+$ workers.

\section{MATERIAL AND METHODS}

The research was conducted among 500 workers aged $50+$ (250 women and 250 men) who were employed at small (10-49 workers), middle (50-249 workers) and big (over 249 workers) companies that represent section 5 of the Polish Classification of Activity (PKD 2007) (3): Manufacturing, Construction, Wholesale and Retail Trade and the Repair of Motor Vehicles, Administrative and Support Service Activities, Human Health and Social Work Activities. Given the structure of companies in Poland (4), micro-enterprises (0-9) were not included in the research as their number is the highest, and in this case, proportional sampling could lead to their overrepresentation. The sampling was of amount and quota nature and was conducted by taking into account three key features: gender, size of the business, affiliation to one of PKD 2007 sections. The selection of companies was performed in Mazovian Voivodship. The persons, who participated in the study, represented both private companies (250 persons) and public sector ( 250 persons). The sample $\mathrm{N}=500$ (at confidence level 0.95 , estimated fraction of 0.5 and maximal error of 0.04 ) was chosen from the population $\mathrm{N}=8000$.

The selection of the types of economic activity was determined by GUS (Główny Urząd Statystyczny Central Statistical Office of Poland) study (5), which clearly indicates that the three chosen sections have the biggest number of employees over 50 years old.
In the study, the diagnostic poll method was applied with anonymous survey that was developed for the purpose of the study on the basis of available reference material (6-9). It contained several parts regarding such aspects as:

recruitment (questions related to the benefits of hiring 50+ workers; factors taken into account while recruiting 50+);

lifelong learning, professional development (questions about: type of training in which $50+$ workers take part, possibilities of further education for $50+$ workers, training of younger employees provided by older employees, training of older employees provided by younger colleagues, promoting older employees); organization of work and working conditions (questions about: flexible working time, extra leave, mobility between positions, more frequent inspections of working stations of $50+$ workers; modification of working stations, occupational safety and health, the needs of $50+$ workers as to the organization of work and working conditions);

health (health care) of 50+ workers (questions about: package of medical services, passes to physical activities, training/counseling related to healthy lifestyle, training/counseling related to aging and the methods of its delaying, training/counseling related to occupational safety and health).

\section{Statistical analysis of results}

The statistical analysis was carried out using SPSS 16.0 software. Chi-square test was used to analyze the relation between the tested variables.

\section{Description of the examined sample}

From among the tested employees, the oldest person was 75 years old. The average length of service varied between 16 and 53 years and, at the present place of employment, during the survey, it ranged from 1 to 40 years. The biggest group comprised of persons with post-secondary education or secondary professional education $(33 \%)$ and persons performing mental work (40\%). In terms of positions, most of the examined persons (20\%) worked as "personal service workers and vendors", at the second place there were "specialists" (about 19\%). As to the positions, the study shows significant statistical differences between men and women. Considerably more women than men were employed as office workers (23.2\% and 6.8\% respectively). However, at managerial positions men were employed slightly more often than women (Table 1). The remaining data describing the group tested is shown in Table 1. 
Table 1. Characteristics of the study group

Tabela 1. Charakterystyka badanej grupy

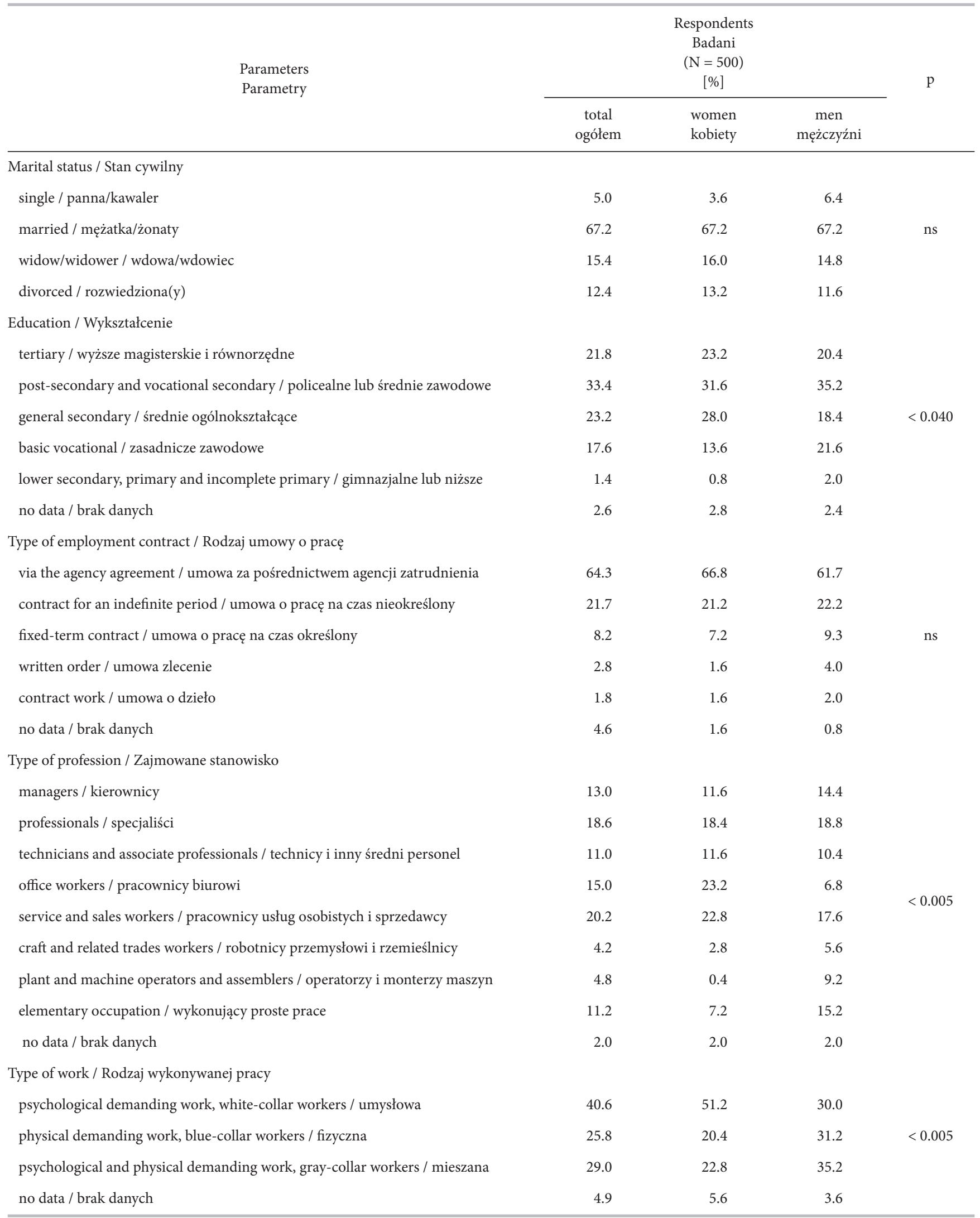

ns - not significant / nieistotne statystycznie. 


\section{RESULTS}

About 25\% persons (incl. 25\% of women and 21\% of men) changed their job after turning 50 years old. The respondents mentioned various reasons which were grouped into a few categories according to the frequency they were mentioned:

redundancy ("older workers were laid off"), dissolution of the company,

health problems,

getting other (better-paid) job,

retiring and getting another extra job,

no qualifications.

Over $93 \%$ of the respondents ( similar figures for men and women) revealed that they maintain good relations with younger colleagues. More than $87 \%$ of workers felt they were necessary for their companies. Moreover, a significant proportion of persons (almost 80\%) felt they were recognized at their companies for their knowledge and experience. More than half of the respondents did the job that corresponded to their learned profession and skills. Only $1 / 5$ of the tested persons were discriminated for their age (Table 2).

\section{Recruitment}

Most of the respondents admitted that during the recruitment process, companies focus mainly on knowledge, skills, experience and education. At the same time, more than $40 \%$ revealed that the age of an employee is also significant (Table 3 ).

\section{Lifelong training / professional development}

Overall, almost $40 \%$ of workers admitted that $50+$ workers take part in all courses, trainings, conferences organized by their companies, but only around $25 \%$ of workers admitted that at their companies, there have been trainings, courses, conferences addressed specially to older workers. More than $37 \%$ of workers claimed that they are provided with trainings/courses that improve skills. A large percentage of workers (43\%) indicated they

Table 2. General feelings of 50+ workers related to their work

Tabela 2. Ogólne odczucia pracowników 50+ dotyczące ich pracy

\begin{tabular}{|c|c|c|c|c|}
\hline \multirow[t]{2}{*}{$\begin{array}{l}\text { Feelings } \\
\text { Odczucia }\end{array}$} & \multicolumn{3}{|c|}{$\begin{array}{c}\text { Respondents } \\
\text { Badani } \\
(\mathrm{N}=500) \\
{[\%]}\end{array}$} & \multirow[t]{2}{*}{$\mathrm{p}$} \\
\hline & $\begin{array}{c}\text { total } \\
\text { ogółem }\end{array}$ & $\begin{array}{l}\text { women } \\
\text { kobiety }\end{array}$ & $\begin{array}{c}\text { men } \\
\text { mężczyźni }\end{array}$ & \\
\hline I feel discriminated / Czuję się dyskryminowana(y) w firmie & 18.0 & 18.0 & 18.0 & ns \\
\hline I feel that I'm needed in the company / Czuję się potrzebna(y) w firmie & 86.8 & 90.0 & 83.6 & $<0.04$ \\
\hline $\begin{array}{l}\text { I have a sense of recognition in the company because of my knowledge/experience / Czuję, że mam } \\
\text { uznanie w firmie ze względu na moją wiedzę/doświadczenie }\end{array}$ & 79.6 & 80.0 & 79.2 & ns \\
\hline My work tasks are / Powierzane mi prace są: & & & & ns \\
\hline $\begin{array}{l}\text { consistent with my learned profession, but overstated in relation to my skills / zgodne z wyuczonym } \\
\text { zawodem, ale zawyżone w stosunku do moich umiejętności }\end{array}$ & 13.4 & 10.4 & 16.4 & \\
\hline $\begin{array}{l}\text { consistent with my learned profession, but understated in relation to my skills / zgodne z wyuczonym } \\
\text { zawodem, ale zaniżone w stosunku do moich umiejętności }\end{array}$ & 5.4 & 6.0 & 4.8 & \\
\hline $\begin{array}{l}\text { inconsistent with the learned profession, but my skills are corresponding / niezgodne z wyuczonym } \\
\text { zawodem, ale odpowiadające moim umiejętnościom }\end{array}$ & 16.8 & 20.4 & 13.2 & \\
\hline $\begin{array}{l}\text { inconsistent with the learned profession and overstated in relation to my skills / niezgodne } \\
\mathrm{z} \text { wyuczonym zawodem i zawyżone w stosunku do moich umiejętności }\end{array}$ & 5.2 & 5.6 & 4.8 & \\
\hline $\begin{array}{l}\text { inconsistent with the learned profession and understated in relation to my skills / niezgodne } \\
\text { z wyuczonym zawodem i zaniżone w stosunku do moich umiejętności }\end{array}$ & 3.6 & 2.8 & 4.4 & \\
\hline
\end{tabular}


Table 3. Types of activities in the company undertaken with reference to 50+ workers

Tabela 3. Rodzaje działań podejmowanych w firmie ukierunkowanej na pracowników 50+

\begin{tabular}{|c|c|c|c|c|}
\hline \multirow[t]{2}{*}{$\begin{array}{l}\text { Activities } \\
\text { Działania }\end{array}$} & \multicolumn{3}{|c|}{$\begin{array}{l}\text { Respondents } \\
\text { Badani } \\
(\mathrm{N}=500) \\
{[\%]}\end{array}$} & \multirow[t]{2}{*}{$\mathrm{p}$} \\
\hline & $\begin{array}{c}\text { total } \\
\text { ogółem }\end{array}$ & $\begin{array}{l}\text { women } \\
\text { kobiety }\end{array}$ & $\begin{array}{c}\text { men } \\
\text { mężczyźni }\end{array}$ & \\
\hline education / wykształcenie & 61.6 & 66.8 & 56.4 & $<0.05$ \\
\hline experience / doświadczenie & 79.8 & 80.0 & 78.8 & ns \\
\hline knowledge and skills / wiedza i umiejętności & 80.4 & 82.4 & 78.4 & ns \\
\hline computer skills / obsługa komputera & 48.6 & 53.6 & 43.6 & $<0.02$ \\
\hline \multicolumn{5}{|l|}{ Professional development / Rozwój zawodowy } \\
\hline $\begin{array}{l}\text { participation of 50+ workers in all conferences, trainings, courses offered by companies / uczestnictwo } \\
\text { pracowników } 50+\text { we wszystkich konferencjach, szkoleniach, kursach oferowanych przez firmę }\end{array}$ & 39.8 & 43.2 & 36.4 & ns \\
\hline Trainings for 50+ workers / Adresowanie szkoleń do pracowników 50+ & 24.8 & 26.4 & 23.2 & ns \\
\hline update trainings, expending knowledge / szkolenia aktualizujące/poszerzające wiedzę & 40.2 & 44.0 & 36.4 & $<0.01$ \\
\hline trainings, courses / szkolenia, kursy podnoszące kwalifikacje & 37.4 & 39.6 & 35.2 & $<0.01$ \\
\hline computer courses / kursy komputerowe & 27.8 & 30.0 & 25.6 & $<0.00$ \\
\hline proposed, but I wasn't interested / proponowano, ale nie byłam $(\mathrm{em})$ zainteresowany & 6.2 & 6.0 & 6.4 & \\
\hline not proposed / nie proponowano & 43.0 & 38.4 & 47.6 & \\
\hline $\begin{array}{l}\text { Encouragement of employees to further their education (e.g. through funding, additional leave) / } \\
\text { Zachęcanie pracowników do dalszego kształcenia (np. poprzez dofinansowanie, dodatkowe urlopy) }\end{array}$ & 23.2 & 22.0 & 24.4 & ns \\
\hline $\begin{array}{l}\text { Involving } 50+\text { employees in the training of younger workers / Angażowanie pracowników 50+ } \\
\text { w szkolenie młodszych pracowników }\end{array}$ & 46.4 & 44.8 & 48.0 & ns \\
\hline $\begin{array}{l}\text { The participation of } 50+\text { workers in training by younger workers (e.g. on computer operation } \\
\text { or new information technologies) / Szkolenie pracowników } 50+\text { przez młodszych pracowników } \\
\text { (np. w zakresie obsługi komputera lub nowych technologii informacyjnych) }\end{array}$ & 37.8 & 44.0 & 31.6 & $<0.010$ \\
\hline Promotion of 50+ workers / Awansowanie pracowników 50+ & 35.6 & 31.6 & 39.6 & ns \\
\hline \multicolumn{5}{|l|}{$\begin{array}{l}\text { Equal (compared with younger) access to the resources of companies / Równy (w porównaniu } \\
\text { z młodszymi) dostęp pracowników 50+ do zasobów firmy }\end{array}$} \\
\hline materials, information / materiały, informacje & 76.0 & 76.8 & 75.2 & ns \\
\hline trainings, courses / szkolenia, kursy & 63.2 & 61.6 & 64.8 & ns \\
\hline
\end{tabular}


Table 3. Types of activities in the company undertaken with reference to $50+$ workers - cont.

Tabela 3. Rodzaje działań podejmowanych w firmie ukierunkowanej na pracowników 50+ - cd.

\begin{tabular}{|c|c|c|c|c|}
\hline \multirow[t]{2}{*}{$\begin{array}{l}\text { Activities } \\
\text { Działania }\end{array}$} & \multicolumn{3}{|c|}{$\begin{array}{c}\text { Respondents } \\
\text { Badani } \\
(\mathrm{N}=500) \\
{[\%]}\end{array}$} & \multirow[t]{2}{*}{$\mathrm{p}$} \\
\hline & $\begin{array}{c}\text { total } \\
\text { ogółem }\end{array}$ & $\begin{array}{l}\text { women } \\
\text { kobiety }\end{array}$ & $\begin{array}{c}\text { men } \\
\text { mężczyźni }\end{array}$ & \\
\hline $\begin{array}{l}\text { work conditions are good and meet my needs / warunki pracy są dobre i odpowiadają moim } \\
\text { potrzebom }\end{array}$ & 74.0 & 74.0 & 74.0 & ns \\
\hline possibility to work flexible hours / możliwość pracy w elastycznym czasie & 44.2 & 43.6 & 44.8 & ns \\
\hline opportunity to get paid leave / możliwość otrzymania dłuższego lub dodatkowego urlopu & 42.2 & 42.0 & 42.4 & ns \\
\hline $\begin{array}{l}\text { opportunity to get paid leave for further education / możliwość otrzymania płatnego urlopu } \\
\text { w celu dalszego kształcenia się }\end{array}$ & 18.0 & 16.8 & 19.2 & ns \\
\hline $\begin{array}{l}\text { transfers between functions, subject to the salary / przeniesienia między stanowiskami, } \\
\text { z zachowaniem wynagrodzenia }\end{array}$ & 28.0 & 28.0 & 28.0 & ns \\
\hline $\begin{array}{l}\text { more frequent inspections of working conditions with reference to health and safety / częstsze } \\
\text { kontrole warunków pracy w kontekście zdrowia i bezpieczeństwa }\end{array}$ & 29.8 & 26.4 & 33.2 & ns \\
\hline \multicolumn{5}{|l|}{ Health care / Ochrona zdrowia } \\
\hline free medical service packages / bezpłatne pakiety usług medycznych & 25.2 & 26.0 & 24.4 & ns \\
\hline free vouchers for physical activity / bezpłatne karnety na zajęcia fizyczne (sport) & 35.0 & 31.6 & 38.4 & ns \\
\hline $\begin{array}{l}\text { training, counseling on healthy lifestyle / szkolenia, poradnictwo dotyczące prozdrowotnego } \\
\text { stylu życia }\end{array}$ & 20.6 & 20.4 & 20.8 & ns \\
\hline $\begin{array}{l}\text { training advice on the process of aging and the possibility of delaying it / szkolenia, poradnictwo } \\
\text { dotyczące procesów starzenia i możliwości ich opóźniania }\end{array}$ & 13.6 & 13.2 & 14.0 & ns \\
\hline $\begin{array}{l}\text { training, counseling on healthy and safe working conditions / szkolenia, poradnictwo dotyczące } \\
\text { zdrowych i bezpiecznych warunków pracy }\end{array}$ & 29.8 & 26.4 & 33.2 & ns \\
\hline
\end{tabular}

Abbreviations as in Table 1 / Objaśnienia jak w tabeli 1.

have not been offered any training or courses. Almost 36\% of the respondents reported that at their companies, older workers are promoted to higher positions. More than $46 \%$ of workers have been involved in the training of their young colleagues (mentoring) and almost 38\% indicated they had been trained by younger workers (Table 3 ). 


\section{Health care}

Only about $20 \%$ of workers declared that their companies have provided counseling concerning healthy lifestyle, but merely $14 \%$ of them indicated that they were trained about aging processes and possibilities of delaying them. About a quarter of older workers have been offered free medical services packages and 35\% of them got free passes to physical activities (sport). About $30 \%$ of the respondents pointed out that their companies had provided training/counseling regarding occupational safety and health (Table 3 ).

\section{Organization of work and working conditions}

Only about $36 \%$ of the respondents declared that they were asked about job satisfaction as to its organization and working conditions. More than $70 \%$ pointed out that their working conditions were good and met their needs. More than a half of them reported that their workplaces were regularly checked and adapted to their needs. Almost $45 \%$ of workers declared they had a chance to work flexible working hours. About $40 \%$ of them admitted that their working stations were adjusted to their needs (Table 3 ).

When answering open-ended question, about $1 / 5$ of workers admitted that at their companies, steps addressed to older workers should be taken. The activities mentioned by the respondents were grouped into several groups according to the frequency they were mentioned:

improving qualifications,

computer courses and new technology trainings,

foreign language courses,

health care (free packages of medical services, fitness cards),

healthy lifestyle counseling (care for physical and mental health, fighting stress),

organization of work (flexible working hours, extra leave).

Older workers were also asked an open-ended question about health problems they would like to obtain information about. The answers can be divided into several categories, according to the frequency they were mentioned:

cardiovascular diseases,

health issues of 50+ persons (incl. 50+ women),

women's diseases,

musculoskeletal problems,

diabetes, obesity,

stress, depression,

vision, hearing.
Older workers were asked an open-ended question about working environment factors that in their opinion, might cause some difficulties or medical problems in the future. Among the most frequently mentioned factors there were: noise (22.6\%) manual labour / carrying heavy items (13.9\%), stress (31.3\%), chemicals / dust / pollution (7.7\%), sitting position at the computer $(8.2 \%)^{1}$.

The analysis of the health condition, health problems and ability to work of older workers will be presented in the next article.

\section{OVERVIEW}

The aim of the present study is to evaluate the activities which, in the opinion of 50+ workers, should be carried out to maintain their employment.

Almost 94\% admitted that they had good relations with their younger colleagues, and $87 \%$ felt needed at their companies. Only about $1 / 5$ of workers admitted that they are discriminated at their companies. This result, however, is worse than the one presented in other studies conducted in Poland (10) which pointed out that a small proportion of people - only 6\% in 2009 and $7 \%$ in 2010, admitted they were discriminated at work due to their age. This was more common among women and persons with basic vocational education.

The present study shows that almost half of $50+$ workers (about $45 \%$ ) have the possibility to work flexible hours. It is a surprisingly high result as compared to the results of the studies carried out by Kononowicz et al. (10), which showed that every fourth company employing $50+$ persons and using flexible working hours does not apply them to older workers. There are some limitations of the interpretation of such a result. On the one hand, one of the reasons for such a result may be a failure to explain to respondents what flexible working hours are, on the other hand, it may have been caused by the lack of information from the respondents themselves on what it meant to them.

Many older workers prefer flexible working hours, in some cases, it could be shorter working hours, partial retirement, changes of work rhythm or working shifts, longer leave, job rotation, reducing overtime or additional responsibilities. Flexible working hours could play a key role at maintaining personnel, achieving company goals as well as increasing productivity and employees' motivation and satisfaction (11).

\footnotetext{
${ }^{1}$ Frequency rates were calculated within a sample of $\mathrm{N}=208$ (292 - no data).
} 
At companies with flexible working hours, the rate of sickness absence is lower, which, in turn, positively affects their overall productivity and competitiveness. Flexible working hours also promote better workhome balance. Studies conducted in Europe show that work-home balance is a major priority for a significant number of workers (11).

The data presented shows that only $28 \%$ of older workers have had a chance to change working place maintaining the same salary. The studies of Kononowicz et al. (10) show that the employees of $35 \%$ of companies had such an opportunity in 2010 (in 2009 this percentage was higher and equaled $47 \%$ ).

Only $25 \%$ of the $50+$ workers taking part in own studies declared that their companies provided training dedicated to their age group and nearly $39 \%$ admitted they had participated in trainings on such topics as: update/expansion of knowledge, raising qualifications, computer training and foreign language courses. Only $23 \%$ of the respondents admitted they were encouraged to further their education, for example through subsidies or extra leave.

The studies of Kononowicz et al. (10) show that in $2010,36 \%$ of companies declared that over the period of 12 months prior to the study, they had organized training (other than occupational safety and health or fire safety). In 2010 one could observe a growth in the percentage of companies declaring that 50+ workers had participated in training (from $61 \%$ in 2009 to $85 \%$ in 2010 ). This opportunity was more common at companies with more than 50 workers than in the smaller ones.

Older persons, i.e. those aged between 55 and 64, are the group of workers who rarely participate in training. The reasons for this are numerous: most often it is due to the lack of time caused by work or family matters, lack of awareness and motivation - such training is not always appreciated or rewarded, lack of information about available trainings, lack of financial resources. Among other barriers for further education, the following are also mentioned: fear of the unknown, insecurity, lack of faith in one's abilities. It must be noted that the motivation of older workers to further their education may often be apparent - it is rather due to the fear of losing the job for not undertaking it (12).

There is an opinion (stereotype) that persons over 50 years old are reluctant to improve their qualifications, i.e. taking part in training. The in-depth interviews conducted by Kononowicz et al. (10) show that this problem does not exist at job positions the nature of which forces continuous learning. The quantitative analysis of the same study indicates that ordinarily older workers willingly take part in trainings (45\%, 27\% disagree).

The above mentioned studies show that the smallest number of activities dedicated to older workers concerned their health. Only 1/4 of the respondents told that they had free medical service packages, but nearly $1 / 4$ of them had received training related to healthy lifestyle, and only $14 \%$ of them got training related to aging processes and the ways of delaying it. Health promotion at workplace is insufficient. Most often, health care at workplace is reduced to complying with the provisions of occupational safety and health. This has been confirmed by the study conducted by the Nofer Institute of Occupational Medicine in Łódź (Poland) (13). It shows that $44 \%$ out of the 1128 surveyed persons admitted that at their companies, care for health was limited only to the compliance with the provisions of occupational safety and health. Almost $40 \%$ of respondents said their companies organized additional activities related to health, but $18 \%$ indicated they were meant for selected groups. However, almost $15 \%$ admitted their companies did not take care after employees' health at all.

Providing occupational safety and health training or facilitating the development of workers' skills is the employer's responsibility (Article 17 of the Polish Labour Code) (14), but providing special training for older workers that would meet their individual needs depends on the goodwill of employers.

The literature of the subject shows that healthy, satisfied and motivated workers create good and strong teams. Therefore, actions must be taken to promote health, maintain/improve the ability to work and the well-being of employees (not only older ones) $(15,16)$.

In the light of the presented results, health care of workers and their individual attitude to it seem to be crucial in the context of extending working age in Poland with maintaining the ability to work. There is a number of age-related physical and psychological changes. These changes, however, can be moderated by increasing physical activity, intellectual activity and other lifestyle-related factors (17).

According to the study conducted by the Finish Institute of Occupational Health, for older workers, health promotion in the workplace has a positive impact on their health, ability to work, job satisfaction and productivity (18). However, as the studies conducted in companies show, such actions are still rare in Poland (19).

With older retiring workers, enterprises (companies) lose knowledge and experience which older workers are 
a valuable source of. On the other hand, older workers often cannot keep up with the pace of work, their ability to work is reduced and the risk of premature diseases increases (20). It is, therefore, necessary that companies take appropriate preventive measures in the form of skillful human resources management by implementing, for instance, transfer of knowledge between older and younger workers, flexible working forms, opportunities for trainings for older workers and improving working conditions (21).

Demographic and economic conditions indicate the need to prolong working activity. Encouraging older workers to stay employed for longer is, however, justified only if parallel actions are taken in the field of age management and maintaining the ability to work (22).

\section{CONCLUSIONS}

Activities related to age management in Poland are still unsatisfactory. Even more disturbing is the low number of respondents who admitted that in their companies, there were activities related to health promotion. From the perspective of the ability to work and extending the retirement age such initiatives should be carried out on a large scale among workers of all ages with special emphasis put on older workers. It seems that conducting activities aimed at changing the health habits of workers may be beneficial for workers themselves (better wellbeing, ability to work) and employers (less absence from work, bigger productivity and efficiency).

Basing on the present study, it can be argued that the most important activities to be taken in order to maintain the employment of $50+$ workers are: organization of work and its conditions, health care and health promotion and lifelong training.

Lifelong training of 50+ workers, despite their vast knowledge and experience, is necessary for their active participation in professional life, well-being in the working environment and maintaining good relations with their younger colleagues. The conducted studies show that stronger emphasis should be put on the organization of training activities dedicated to $50+$ workers and corresponding to their needs.

Older workers have different needs than younger ones as to the organization of work and its conditions. It refers to working time, shifts work, adjusting working spaces or shifting between different positions. Therefore, there is a need to pay special attention to the analysis of older workers' needs and, thus, adapting working conditions to their abilities.

\section{REFERENCES}

1. Employment rate of older workers [cited 2012 Juni 25]. Available from URL: http://epp.eurostat.ec.europa.eu/ portal/page/portal/product_details/dataset?p_product_ code $=$ TSDDE 100 .

2. Walker A. Managing an ageing workforce: A guide to good practice. Dublin: European Foundation for the Improvement of Living and Working Conditions; 1999.

3. The Council of Ministers of 24 December 2007 on the Polish Classification of Economic Activities [cited 2012 Juni 25]. Available from URL: http://www.stat.gov.pl/klasyfikacje/pkd_07/pdf/rozp_24_XII_2007.pdf [in Polish].

4. Report on the state of small and medium-sized enterprises in Poland. Warszawa: PARP; 2010 [in Polish].

5. Zwara W. People over 50 on the labour market. Warszawa-Bydgoszcz: GUS; 2012 [in Polish].

6. Naegele G, Walker A. A guide to good practice in age management [cited 2012 Juni 25]. Luxembourg: European Foundation for the Improvement of Living and Working Conditions; 2006. Available from URL: http://www.eurofound.europa.eu/pubdocs/2005/137/ en/1/ef05137en.pdf.

7. Council Directive 2000/78/EC of 27 November 2000 establishing a general framework for equal treatment in employment and occupation. Employment Framework Directive [cited 2012 Juni 25]. Available from URL: http://eurlex.europa.eu/LexUriServ/LexUriServ.do ?uri=CELEX:32000L0078:en:HTML.

8. Older Workers Recommendation, Recommendation No. 162 [cited 2012 Juni 25]. Available from URL: http://www. ilo.org/dyn/normlex/en/f?p=NORMLEXPUB:12100:0::N O:12100:P12100_ILO_CODE:R162.

9. The programme "Solidarity between generations. Actions to increase the activity of people aged 50+" [cited 2012 Juni 25]. Available from URL: http://www.mpips.gov.pl/ bip/akty-prawne/programy/program-solidarnosc-pokolen-dzialania-dla-zwiekszenia-aktywnosci-zawodowejosob-w-wieku-50 [in Polish].

10. Kononowicz M, Michałowska J, Majewska A. People aged 50+ in the Mazowieckie labor market. Results from studies conducted between 2009 and 2010. Sopot: PBS DGA Sp. z o.o. Human Capital Business Sp. z o.o.; 2010 [in Polish].

11. Flexible working time and work-life balance [cited 2012 Juni 25]. Available from URL: http://www.eurelectric.org/ Demographic/2008DemographicChangep13.html.

12. Urbaniak B, Samson H, Kołodziejczyk-Olczak J, Wieczorek J, Michno L. How to encourage employees over 45 years for further education. Recommendations for practicion- 
ers [cited 2012 August 21]. Warszawa: The United Nations Development Programme (UNDP); 2008. Available from URL: http://www.zysk50plus.pl/storage/fck/file/ PUBLIKACJE/edukacja_sojuszdlapracy.pdf [in Polish].

13. Korzeniowska E. Health beliefs and Health behavior in older employees of medium-size and large enterprises. Med Pr 2004;55(2):129-38 [in Polish].

14. Kodeks pracy [cited 2012 Juni 25]. Available from URL: http://kodeks-pracy-rp.org [in Polish].

15. Knauth P, Karl D, Braedel-Kühner C. How to improve the work ability of elderly workers. The European research project RESPECT. In: Costa G, Goedhard WJA, Ilmarinen J. Assessment and promotion of work ability, health and well-being of ageing workers. Int Congr Series 2005;1280:11-16. Http://dx.doi.org/10.1016/j. ics.2005.02.046

16. Hildt-Ciupińska K, Bugajska J. The role of pro-health behaviors in promoting workers' health. Bezpiecz Pr Nauka Prakt 2011;9(480):10-13[in Polish].

17. Crawford JO, Graveling RA, Cowie H, Dixon K, MacCalman L. The health safety and health promotion needs of older workers. Edinburgh: IOSH; 2009.
18. Naumanen P. The health promotion of aging workers from the perspective of occupational health professionals. Public Health Nurs 2006;23(1):37-45. Http://dx.doi. org/10.1111/j.0737-1209.2006.230106.x

19. Bugajska J, Hildt-Ciupińska K. Evaluation of activities targeted at employability of older workers in polish enterprises. Med Pr 2012;63(4):453-62 [in Polish].

20. Ziekemeyer M. Age diverse and a method for age proofing jobs. Int Congr Series 2005;1280:421-7. Http://dx.doi. org/10.1016/j.ics.2005.03.031.

21. Bugajska J, Makowiec-Dąbrowska T, Wągrowska-Koski E. Age management in enteprises as a part of occupational safety and health in elderly. Med Pr 2010;61(1):55-63 [in Polish].

22. Streb ChK, Voelpel S, Leibold M. Managing the aging workforce: status quo and implications for the advancement of theory and practice. Eur Manag J 2008;26(1):1-10. Http://dx.doi.org/10.1016/j.emj.2007.08.004. 